\title{
Potato mosaic viruses which infect plants of tuber-bearing Solanum spp. growing in the VIR field gene bank
}

\author{
E.V. Rogozina ${ }^{1} \otimes$, N.V. Mironenko ${ }^{2}$, N.A. Chalaya ${ }^{1}$, Yu. $^{\text {Matsushita }}{ }^{3}$, H. Yanagisawa ${ }^{4}$ \\ ${ }^{1}$ The N.I. Vavilov All-Russian Institute of Plant Genetic Resources (VIR), St. Petersburg, Russia \\ ${ }^{2}$ All-Russian Institute of Plant Protection, Pushkin, St. Petersburg, Russia \\ ${ }^{3}$ Institute of Vegetable and Floriculture Science, National Agriculture and Food Research Organization, Tsukuba, Japan \\ ${ }^{4}$ Central Region Agricultural Research Center, National Agriculture and Food Research Organization, Tsukuba, Japan \\ 凶e-mail: erogozina@vir.nw.ru
}

Potato crop is particularly affected by virus diseases, and potato virus Y (PVY) currently considered the most important pathogen distributed worldwide as a diversity of strains. Wild and cultivated tuber-bearing species of the genus Solanum L., stored in the VIR collection, are used as the initial material in creation domestic potato varieties (Solanum tuberosum L.) resistant to virus diseases. The preservation and rational utilization of the potato collection is based on regular phytosanitary monitoring, including quarantine objects, foremost PSTVd (potato spindle tuber viroid). The aim of the work is to examine plants of tuber-bearing Solanum species in the field gene bank of VIR for the presence of PSTVd and PVX (potato virus X), PVS (potato virus S), PVM (potato virus M) and PVY, which are the most common viruses on potatoes in the North-West District of Russia. We examined clonal plants of 137 genotypes representing 31 species of the section Petota of the genus Solanum L. A diagnostic was carried out using ELISA, RT-PCR and indicator plants. No PSTVd was found in the studied plants, but a plural infestation by mosaic viruses was detected, more than half of the tested clones are infected with two or more viruses. In the studied samples, only 17 genotypes (12\%) are not infected by PVX, PVS, PVM and PVY according to the ELISA test. There are statistically significant differences in the virus infestation of Solanum species with different origins, according to Pearson's chi-squared test. Among the studied genotypes of wild relatives of potatoes, the proportion of those affected by PVY was significantly higher in the South American than in the North American species $\left(\chi^{2}=4.56\right.$, $p=0.03)$; the proportion of genotypes affected by PVX was significantly higher in the North American species $\left(\chi^{2}\right.$ $=8.81, p=0.003)$, the critical value was $\chi^{2}=3.841$. PVY strains were identified by multiplex RT-PCR in 37 genotypes of Solanum spp. We found that 27 genotypes are infected by a common PVYO strain, two genotypes are infected by PVYNW (A) and PVYNW (B) strains, respectively, seven genotypes are infected by a mixture of PVYO + PVYNW (A) strains, and one is infected by a mixture of PVYO + PVYNTN-NW (SYRI) + SYRIII strains. The recombinant strains of PVY are detected in the North-West District of Russia for the first time. Coherency of the results of PVY strains detection by various (immunological, molecular and biological) methods is discussed.

Key words: wild tuber-bearing Solanum spp.; potato spindle tuber viroid; potato mosaic viruses; PVY strains; recombinant strains; ELISA; RT-PCR; indicator plant; mixed infection.

For citation: Rogozina E.V., Mironenko N.V., Chalaya N.A., Matsushita Yu., Yanagisawa H. Potato mosaic viruses which infect plants of tuber-bearing Solanum spp. growing in the VIR field gene bank. Vavilovskii Zhurnal Genetiki i Selektsii = Vavilov Journal of Genetics and Breeding. 2019;23(3):304-311. DOI 10.18699/VJ19.495

\section{Мозаичные вирусы картофеля, поражающие растения клубненосных видов рода Solanum L. в полевом генном банке ВИР}

\author{
Е.В. Рогозина ${ }^{1} \otimes$, Н.В. Мироненко ${ }^{2}$, Н.А. Чалая ${ }^{1}$, Ю. Мацухита ${ }^{3}$, Х. Янагисава ${ }^{4}$ \\ ${ }^{1}$ Федеральный исследовательский центр Всероссийский институт генетических ресурсов растений им. Н.И. Вавилова (ВИР), Санкт-Петербург, Россия \\ 2 Всероссийский научно-исследовательский институт защиты растений, Пушкин, Санкт-Петербург, Россия \\ ${ }^{3}$ Институт овощеводства и цветоводства Национальной организации сельского хозяйства и исследований пищевых продуктов, Цукуба, Япония \\ ${ }^{4}$ Центральный сельскохозяйственный научно-исследовательский центр Национальной организации сельского хозяйства \\ и исследований пищевых продуктов, Цукуба, Япония \\ 凶e-mail: erogozina@vir.nw.ru
}

Вирусные болезни наносят большой ущерб картофелеводству, и особую проблему повсеместно представляет вирус картофеля Y (potato virus Y - PVY), отличающийся разнообразием штаммового состава. Для создания отечественных сортов картофеля (Solanum tuberosum L.), устойчивых к вирусным болезням, исходным материалом служат дикие и культурные клубнеобразующие виды рода Solanum L., сохраняемые в коллекции генетических ресурсов картофеля ВИР. Сохранение и рациональное использование коллекции основано на регулярном фитосанитарном мониторинге, в том числе карантинных объектов, в первую очередь - вироида веретеновидности клубней картофеля (рotato spindle tuber viroid - PSTVd). Цель работы обследование растений клубненосных видов Solanum L. в полевом генном банке BИP на наличие PSTVd n 


\begin{abstract}
мозаичных вирусов PVX (potato virus X), PVS (potato virus S), PVM (potato virus M) и PVY (potato virus Y), наиболее распространенных на картофеле в Северо-Западном регионе Российской Федерации. Обследованы клоновые растения 137 генотипов, представляющие 31 вид секции Petota рода Solanum L. Диагностика проведена методами ELISA, OT-ПЦР и растений-индикаторов. Среди изученных растений PSTVd не обнаружен, но диагностировано массовое поражение мозаичными вирусами, более половины тестированных клонов инфицировано двумя и более вирусами. Выявлено 17 генотипов (12\%) с отрицательной реакцией ELISA на PVX, PVS, PVM и PVY. Различия в поражении мозаичными вирусами растений Solanum spp., относящихся к разным филогенетическим группам, статистически значимы (по критерию $\chi^{2}$ Пирсона). Среди исследованных генотипов южноамериканских видов доля пораженных PVY достоверно больше, чем среди генотипов североамериканских видов $\left(\chi^{2}=4.56, p=0.03\right)$, PVX, напротив, чаще детектирован у генотипов из группы североамериканских видов $\left(\chi^{2}=8.81, p=0.003\right)$. Штаммы PVY идентифицировали у 37 генотипов Solanum spp. методом мультиплексной ОТ-ПЦР. Выявлено 27 генотипов, пораженных обычным штаммом PVYО, по одному генотипу - пораженные штаммами PVYNW (A) и PVYNW (B), семь генотипов, пораженных смесью штаммов PVYO + PVYNW (A), и один - смесью штаммов PVYO + PVYNTN-NW (SYRI) и SYRIII. Рекомбинантные штаммы PVYNW (A), PVYNTN-NW (SYRI) и SYRIII впервые обнаружены в Северо-Западном регионе Российской Федерации. Обсуждается согласованность результатов диагностики штаммов PVY разными (иммунологический, молекулярный и биологический) методами.

Ключевые слова: дикие клубненосные Solanum spp.; вироид веретеновидности клубней картофеля; мозаичные вирусы картофеля; штаммы PVY; рекомбинантные изоляты; ELISA; OT-ПЦР; растение-индикатор; смешанная инфекция.
\end{abstract}

\section{Introduction}

In a changing climate, sustainable agricultural production of sufficient volumes of diverse high-quality food products is necessary to provide the population of the world with food.

One of the leading crops in global agriculture is potato, a vegetatively propagated crop, vulnerable to virus infections. No less than 40 potato-infecting virus species are known (Potato Biology..., 2007), of which six are the most harmful and widespread: namely, the potato leafroll virus (PLRV) and the mosaic viruses: potato virus $\mathrm{X}$ (PVX), potato virus $\mathrm{S}$ (PVS), potato virus $\mathrm{M}$ (PVM), potato virus $\mathrm{A}$ (PVA) and potato virus Y (PVY). Virus diseases, especially those that are caused by a mixture of PVY and other viruses of the mosaic group, lead to significant losses in production of the commodity in question and impede seed production. PVY is distinguished by a variety of strains, among which there are five non-recombinant and more than three dozens of recombinant ones (Green et al., 2018). In recent years, in many countries where potatoes are cultivated, including the Russian Federation, there has been a significant spread, and sometimes dominance, of recombinant PVY strains (Karasev, Gray, 2013; Uskov et al., 2016; Green et al., 2017). PVY recombinant isolates represent a particular problem for the potato industry, since many of them cause necrotic lesions or potato tubers fissuring.

An ecologically safe and effective strategy of protecting potatoes from virus infections is based on the development of resistant varieties and their introduction into cultivation. The initial material for potato breeding for resistance to virus diseases is represented by wild and cultivated tuberbearing species of the genus Solanum L. In comparison to other agricultural plants, potatoes have the largest number of tuber-bearing wild relative species (Vincent et al., 2013). According to FAO, at present extensive ex situ collections of potatoes totaling around 98000 accessions are maintained in 30 countries around the world (Machida-Hirano, 2015). The VIR collection of potato genetic resources is among the most representative ones, with about 8000 accessions of wild, primitive and cultivated species, varieties and breeding clones of potato. An important aspect of the work on the conservation and regeneration of the cultivated forms and wild relatives of potato is the phytosanitary monitoring of the collection and control over the non-proliferation of the quarantine objects, first of all, of the Potato spindle tuber viroid (PSTVd). It is transmitted by contact, with the sap of infected plants or botanical seeds, which become infected if they form in plants with infected pollen or ovules. In addition to potato varieties, PSTVd is of high threat to the stolon- and tuber-forming Solanum spp., accessions of which are conserved in genebank collections (Jeffries, 1998). The present study was aimed at monitoring PSTVd, as well as PVX, PVS, PVM and PVY (most common mosaic potato viruses in North-West District of Russia in plants of wild Solanum tuber-bearing species in the field genebank of VIR.

\section{Materials and methods}

The study involved 137 plants representing 31 species of wild tuber-bearing Solanum spp. belonging to such series in the North American group as Demissa Buk. (S. iopetalum), Longipedicellata Buk. (S. fendleri, S. hjertingii, S. papita, S. polytrichon, S. stoloniferum), Pinnatisecta Rydb. (S. jamesii, S. pinnatisectum), Cardiophylla Buk. (S. cardiophyllum, S. ehrenbergii), and such series in the South American group as Acaulia Juz. (S. acaule), Yungasensia Corr. (S. arnezii), Glabrescentia Buk. (S. chacoense), Bukasoviana Gorbat. (S. alandiae, S. avilesii, S. gourlayi, S. hondelmannii, S. kurtzianum, S. leptophyes, S. okadae, S. oplocense, S. sparsipilum, S. spegazzinii, S. venturii, S. vernei), Tarijensia Corr. (S. berthaultii, S. neocardenasii, S. tarjiense), Simpliciora (Buk.) Gorbat. (S. microdontum, S. simplicifolium) and Maglia Bitt. (S. molinae). Names of the series and the species are given in accordance with classifications by S.M. Bukasov (1978) and L.E. Gorbatenko (1990).

The species were represented by 2 to 16 genotypes conserved as clonal plants. The studied Solanum spp. genotypes either constituted a trait-specific collection of wild potato relatives characterized for their resistance to phytopathogens and the presence of the corresponding $R$ gene markers (Rogozina et al., 2014), or were a part of the working collection of geno- 
Table 1. Classification of potato virus Y (PVY) strains, according to the multiplex PCR (Chikh Ali et al., 2010)

\begin{tabular}{|c|c|}
\hline $\begin{array}{l}\text { Products in the multiplex PCR, } \\
\text { bp }\end{array}$ & Identified PVY strain \\
\hline $853+532$ & PVYO \\
\hline $1307+633+398$ & $P V Y^{N}$ \\
\hline 1307 & $N A-P V Y^{N}$ \\
\hline $853+633+441$ & PVYNW (A) \\
\hline $853+441$ & PVYNW (B) \\
\hline $1307+633+441$ & $\mathrm{PVY}^{\mathrm{NTN}}(\mathrm{A})$ \\
\hline $1307+441$ & $\mathrm{PVY}^{N T N}(\mathrm{~B})$ \\
\hline $1076+633+441$ & PVYNTN-NW (SYRI) \\
\hline $1076+441$ & PVYNTN-NW (SYRII) \\
\hline $1076+441+278$ & SYRIII \\
\hline
\end{tabular}

types studied for a set of traits of breeding importance. The plants tested in field conditions were grown from the tubers reproduced annually in protected soil.

Viroid detection. The total RNA was isolated from $100 \mathrm{mg}$ of fresh leaves of wild Solanum spp. using the RNeasy Plant Mini Kit (QIAGEN, Germany), following the manufacturer recommendations. The RNA was used to detect PSTVd viroid by RT-PCR, according to the protocol (Yanagisawa, et al., 2017) envisaging the use of the 6Pospi-F/R primer set. A plant of potato cultivar 'Osen' infected with PSTVd viroid and conserved in the collection of the A.G. Lorch Potato Research Institute (Korenevo, Moscow Province), was used as a positive control.

Virus detection. An ELISA double sandwich method (Clark, Adams, 1977) was used to detect PVX, PVS, PVM and PVY viruses in the leaves of wild Solanum spp. The used diagnostic kits were produced by the "Biotechnology" Scientific Production Association at the A.G. Lorch Potato Research Institute.

For additional detection of PVY, RT-PCR with specific primers was used (San et al., 2009). The PVY strain composition was determined by multiplex RT-PCR using a set of 12 primers (Lorenzen et al., 2006), which allowed identification of 10 individual strains: $\mathrm{PVY}^{\mathrm{O}}, \mathrm{PVY}^{\mathrm{N}}$, NA-PVYN ${ }^{\mathrm{N}}, \mathrm{PVY}^{\mathrm{N}} \mathrm{W}$ (two genotypes), PVY ${ }^{\mathrm{NTN}}$ (two genotypes), PVY ${ }^{\mathrm{NTN}-\mathrm{NW}}$ (two genotypes) and SYRIII (Table 1), as well as the cases of mixed infection with these strains (Chikh Ali et al., 2010). The Prime Script One Step RT-PCR kit (TaKaRa, Japan) was used for RT-PCR; the PCR products were separated on agarose gels and stained with ethidium bromide.

Nicotiana tabacum L. indicator plants ('Samsun' variety) were tested to verify the RT-PCR results for diagnosing and determining the PVY strain composition (Jeffries, 1998).

\section{Results}

PSTVd detection. RT-PCR assay of 137 genotypes of 31 wild tuber-bearing Solanum spp. did not reveal PSTVd in the tested leaf tissue samples, with the exception for the positive control. The obtained results are consistent with the previous testing of other genotypes of wild Solanum species from the
VIR collection for PSTVd presence (T.B. Kastaljeva, pers. commun.) and indicate the absence of PSTVd in accessions of wild potato species in the VIR field genebank.

Potato mosaic viruses detection. Mass infection of plants of wild Solanum species with PVX, PVS, PVM and PVY (Table 2) has been detected by ELISA assay.

Only 17 genotypes (12\% of the tested) were not infected with mosaic viruses. They belong to the species $S$. acaule (k-23004), S. cardiophyllum (k-16827, k-16828), S. gourlayi (k-11446, k-12416), S. hjertingii (k-23366), S. hondelmannii (k-20023), S. leptophyes (k-5764), S. polytrichon (k-19164, k-24410), S. sparsipilum (k-9798, k-19344), S. spegazzinii (k-11422, k-11975, k-12688), S. stoloniferum (k-24420), and $S$. vernei (k-11447). It should be noted that in other genotypes of S. acaule (k-23004) and S. vernei (k-11447), PVY and PVY/ PVS mixed infections were detected, respectively. Clones of Solanum species selected as sources of resistance to late blight or golden nematode, were found to be infected with a monoinfection or a mixture of PVX, PVS and PVY.

The greatest occurrence in plants of a set of studied tuberforming Solanum spp. was demonstrated by PVY, as 58\% of the tested genotypes were infected with this virus. The infection with PVY was detected in $22 \%$ of genotypes, and $36-37 \%$ of genotypes were found to be infected with PVM and PVS (See Table 1). Statistically significant differences between the two groups of potato species were found: among the studied genotypes of Solanum spp. from the South American group, the proportion of those infected with PVY was significantly higher than among the species from the North American group (chi-square value $\chi^{2}=4.56>$ critical chisquare value $\chi^{2}=3.84$ at .05 probability level), while PVX was more often detected in the genotypes of potato species from the North American group (chi-square value $\chi^{2}=8.81>$ critical chi-square value $\left.\chi^{2}=3.84\right)$.

More than half of the genotypes in the studied set of tuber-forming Solanum spp. were infected with two or more mosaic viruses. A mixed infection of all four mosaic viruses was found in plants of nine genotypes belonging to the species S.alandiae, S. fendleri, S. microdontum, S. papita, S. polytrichon, S. simplicifolium and S. stoloniferum. A complex of three viruses was detected in 15 genotypes belonging to the species S. chacoense, S. kurtzianum, S. microdontum, S. molinae, S. pinnatisectum, S. polytrichon, S. simplicifolium and S. stoloniferum.

PVY strains identification. Plants of 40 genotypes representing the species S.alandiae, $S$. avilesii, S. cardiophyllum, S. chacoense, S. ehrenbergii, S. fendleri, S. hjertingii, S. iopetalum, S. jamesii, S. kurtzianum, S. leptophyes, S. neocardenasii, S. pinnatisectum, S. polytrichon, S. simplicifolium, $S$. spegazzinii and $S$. stoloniferum were additionally tested for the presence of PVY by RT-PCR (Sun et al., 2009). PVY was not found in plants of $S$. leptophyes (k-5764) and $S$. neocardenasii (k-24612), which is consistent with ELISA results. The PVY strains were identified by the presence of diagnostic amplification products of various sizes, obtained as a result of multiplex RT-PCR (Chikh Ali et al., 2010). Fig. 1 shows samples of PVY strains identification.

It should be noted that the results of multiplex RT-PCR do not always allow the unambiguous identification of PVY strains. For example, there is an 'extra' amplification product 
Table 2. Potato mosaic virus infection in plants of tuber-bearing Solanum spp. (St. Petersburg, Pushkin, 2016-2017)

\begin{tabular}{|c|c|c|c|c|c|}
\hline \multirow[t]{2}{*}{ Series (number of species) } & \multirow{2}{*}{$\begin{array}{l}\text { No. of tested } \\
\text { genotypes }\end{array}$} & \multicolumn{4}{|c|}{ No. of genotypes with positive ELISA reaction to mosaic viruses } \\
\hline & & PVY & PVX & PVS & PVM \\
\hline \multicolumn{6}{|c|}{ North-American group } \\
\hline Demissa (1) & 2 & 2 & 0 & 2 & 0 \\
\hline Longipedicellata (5) & 40 & 23 & 17 & 19 & 21 \\
\hline Pinnatisecta (2) & 11 & 2 & 2 & 1 & 5 \\
\hline Cardiophylla (2) & 8 & 2 & 2 & 1 & 1 \\
\hline Total & 61 & $29^{\mathrm{a}}$ & $21^{b}$ & 23 & 27 \\
\hline \multicolumn{6}{|c|}{ South-American group } \\
\hline Yungasensia (1) & 2 & 2 & 0 & 1 & 0 \\
\hline Glabrescentia (1) & 10 & 5 & 1 & 8 & 5 \\
\hline Acaulia (1) & 2 & 1 & 0 & 0 & 0 \\
\hline Bukasoviana (12) & 46 & 30 & 4 & 9 & 6 \\
\hline Tarijensia (3) & 4 & 3 & 0 & 2 & 2 \\
\hline Simpliciora (2) & 10 & 8 & 4 & 6 & 9 \\
\hline Maglia (1) & 2 & 2 & 0 & 2 & 1 \\
\hline Total & 76 & $51^{a}$ & $9^{b}$ & 28 & 23 \\
\hline Total genotypes (\%) & $137(100)$ & $80(58)$ & $30(22)$ & $51(37)$ & $50(36)$ \\
\hline
\end{tabular}

Note: The statistically significant differences at a significance level of $a=0.05$ are marked with letters.

of $278 \mathrm{bp}$ in size in lanes 3 and 4 (see Fig. 1); and in lane 6, in addition to the diagnosed strains NA-PVYN (1307 bp) and $\mathrm{PVY}^{\mathrm{O}}$ (853 and $532 \mathrm{bp}$ ), fragments of 1076, 633 and $278 \mathrm{bp}$ are clearly seen, though a $441 \mathrm{bp}$ fragment is lacking for the identification of other recombinant strains.

A total of 27 genotypes were found to be infected with the common $\mathrm{PVY}^{\mathrm{O}}$ strain, one genotype infected with recombinant strains of $\mathrm{PVY}^{\mathrm{N}} \mathrm{W}(\mathrm{A})$ and $\mathrm{PVY}^{\mathrm{N}} \mathrm{W}(\mathrm{B})$, seven genotypes showed infection with a mixture of $\mathrm{PVY} \mathrm{O}^{\mathrm{O}}$ PVY ${ }^{\mathrm{N}} \mathrm{W}$ (A) strains, and one was infected with a mixture of $\mathrm{PVY}^{\mathrm{O}},+\mathrm{PVY}^{\mathrm{NTN}-\mathrm{NW}}$ (SYRI) and SYRIII strains. The results of PVY diagnosing by immunological and molecular methods coincided in $68 \%$ of cases. A discrepancy was observed in the results of the diagnosis of 13 genotypes belonging to S. cardiophyllum, S. fendleri, S. hjertingii, S. kurtzianum, S. polytrichon, S. stoloniferum and $S$. pinnatisectum, which had a negative ELISA, but a positive RT-PCR result.

Indicator plant tests. To verify the results of immunological and molecular analyses, 21 genotypes of Solanum spp. were tested for infection with PVY in a biological test using N. tabacum L. indicator plants. The plants of N. tabacum L. 'Samsun' variety inoculated with sap from plants of 13 Solanum spp. genotypes, in which PVY had been detected, showed symptoms of infection on the 7th day. One group of tobacco plants had an interveinal clearing, followed by mottle, the symptoms of which persisted a month later and kept appearing gradually on new leaves as they grew and developed. These symptoms evidence the infection of tobacco plants with the common $\mathrm{PVY}^{\mathrm{O}}$ strain. In other plants of $N$. tabacum, a severe veinal necrosis and puckering of the leaf tissue were observed, which were followed by chlorosis of the entire leaf and stunting of the plant growth (Fig. 2). These symptoms evidence tobacco infection with a necrotic strain of $\mathrm{PVY}^{\mathrm{N}}$. The visible

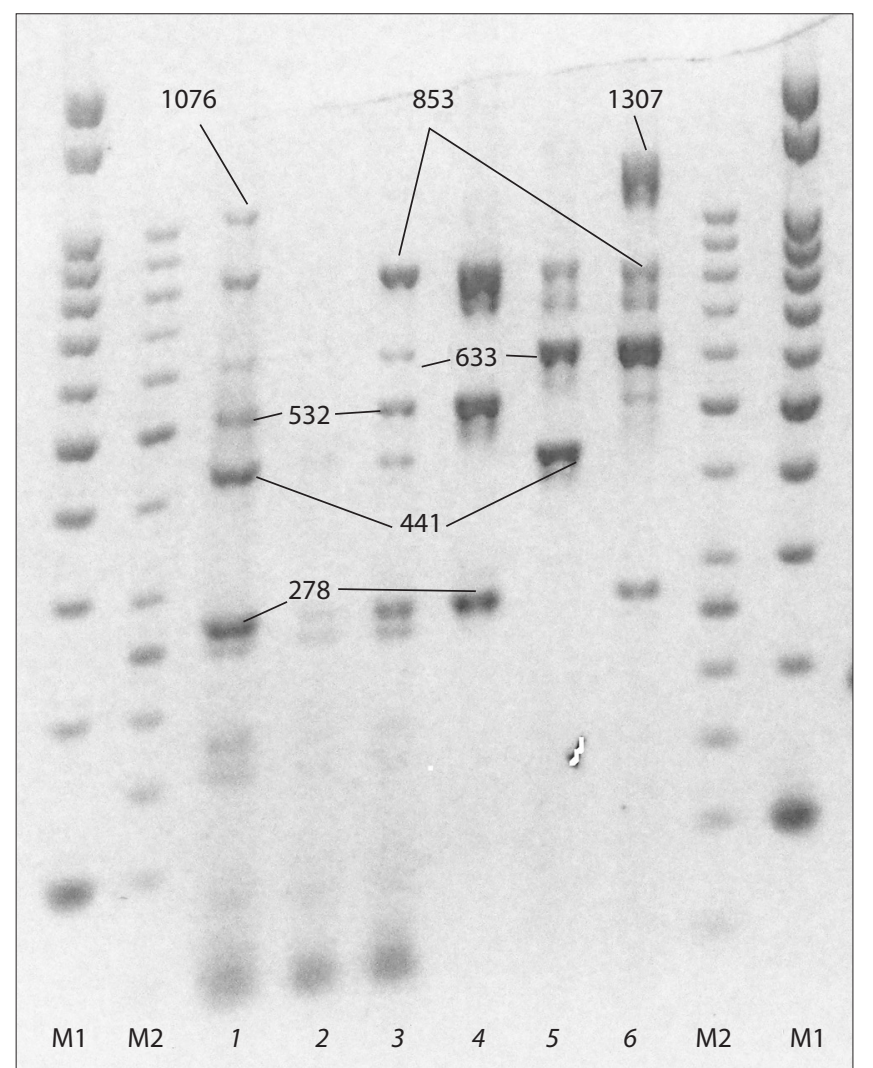

Fig. 1. PVY strains identification in samples of wild Solanum species by multiplex RT-PCR.

DNA molecular size markers $M 1$ and $M 2$ - GeneRuler ${ }^{\mathrm{TM}} 1 \mathrm{~kb}$ and $50 \mathrm{bp}$ (Fermentas DNA Ladder, respectively). Accessions of wild Solanum species: 1 S. cardiophyllum; 2 - S. jamesii; 3 - S. polytrichon; 4 - S. avilesii; 5 - S. iopetalum; 6 - S. jamesii. Numbers indicate diagnostic amplification product size, in bp. The identified PVY strains are presented in Table 3. 
Table 3. PVY strains identification in Solanum spp. accessions according to the amplified products presence in the multiplex RT-PCR (Chikh Ali et al., 2010) (see Fig. 1)

\begin{tabular}{|c|c|c|c|c|}
\hline No. & Solanum spp. & $\begin{array}{l}\text { VIR Catalog } \\
\text { number }\end{array}$ & Size, bp & PVY strain \\
\hline 1 & S. cardiophyllum & 24375 & $1076,853,633,532,441,278$ & PVYO ${ }^{\text {PVYNTN-NW }}$ (SYRI) and SYRIII \\
\hline 2 & S. jamesii & 24920 & Small amount of RNA & Not detected \\
\hline 3 & S. polytrichon & 24410 & $853,633,532,441,278$ & $P V Y^{O}$ and $P V Y^{N} W(A)$ \\
\hline 4 & S. avilesii & 20884 & $853,532,278$ & PVYO \\
\hline 5 & S. iopetalum & 24393 & $853,633,441$ & $P V Y^{N} W(A)$ \\
\hline 6 & S. jamesii & 24920 & $1307,1076,853,633,532,278$ & PVY ${ }^{\circ}$ и NA-PVYN \\
\hline
\end{tabular}

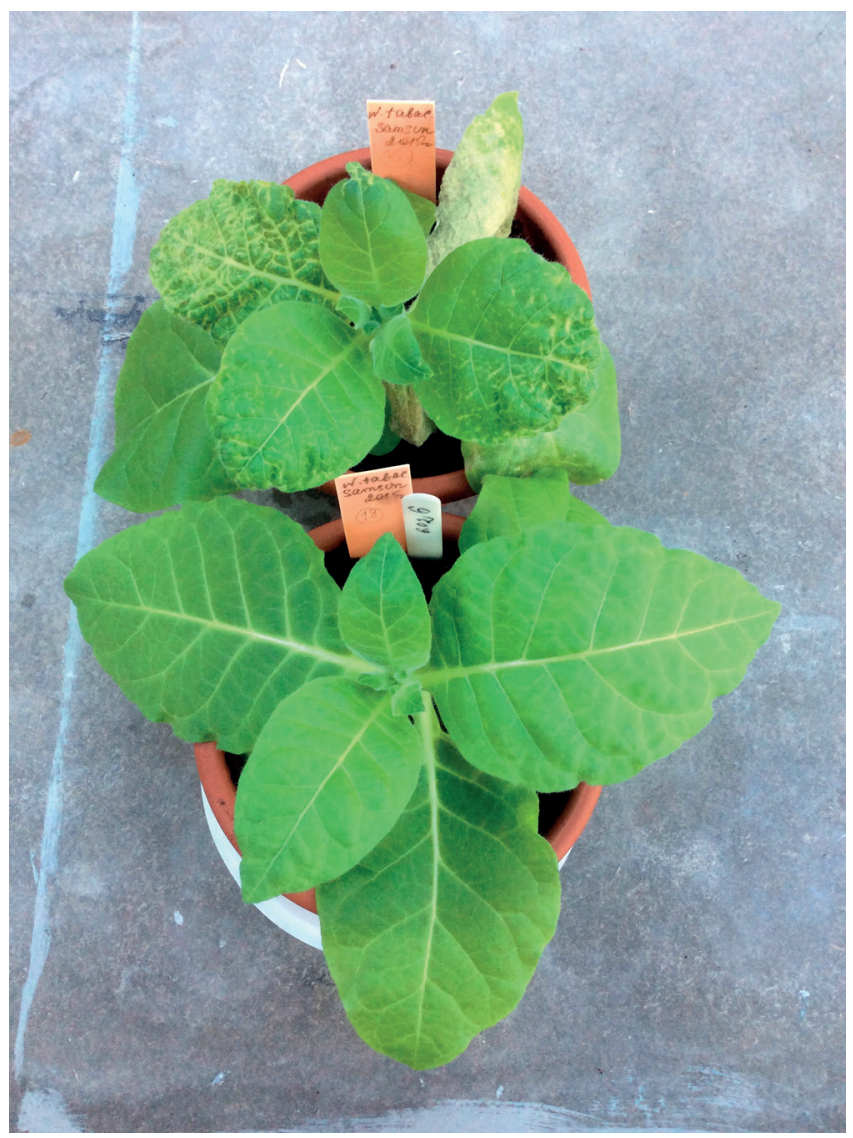

Fig. 2. Symptoms of PVY infection in N. tabacum after inoculation with sap from Solanum spp. plants.

Top - systemic veinal necrosis (PVYN necrotic strain); bottom - veinal clearing symptoms (PVY० common strain).

symptoms of virus infection in $N$. tabacum plants clearly differed depending on the genotypes of Solanum species used as sources of the virus inoculum. In accordance with the local and systemic response observed on the leaves of the indicator plants after inoculation with the sap of the corresponding wild potato plant, infection of eight Solanum spp. genotypes with the common strain and of five Solanum spp. genotypes with the necrotic strain of virus Y has been detected (Table 4).

No symptoms of virus infection were found on tobacco plants after inoculation with the sap of S. leptophyes and
S. neocardenasii plants, which, according to ELISA and multiplex RT-PCR, were PVY-free. The results of PVY detection by the immunological and biological methods coincided for 19 (90\% of the tested) genotypes of Solanum spp. Inoculation with the sap from plants of five genotypes, that is $S$. fendleri, S. hjertingii, S. pinnatisectum (two genotypes), S. cardiophyllum (PVY-infected according to multiplex RT-PCR) and $S$. simplicifolium (with a positive ELISA and RT-PCR reaction) have not caused visible effects in N. tabacum plants. The results of indicator plants tests and of RT-PCR for virus Y detection coincided for 15 (71\% of the tested) genotypes, and the identification of virus $Y$ strain composition coincided for 9 (62\% of the tested) genotypes of Solanum species.

The N. tabacum plants inoculated with sap from Solanum spp. plants were tested for the presence of PVY by RT-PCR. An analysis of 12 phenotypically different tobacco plants confirmed the presence of the virus in 10 test samples (See Table 4). The results of the strain composition determination from the symptoms and by RT-PCR of indicator plants coincided (or partially coincided) for seven genotypes: S. avilesii (k-20884 and k-20158), S. iopetalum (k-24393), S. jamesii (k-24920) (221), S. polytrichon (k-18142, k-24410 and k-24462). For the genotypes of $S$. chacoense (k-21321) and S. kurtzianum (k-20038), the virus Y necrotic strain identified by the response of the indicator plant, did not match the results of RT-PCR. For S. cardiophyllum (k-24375) infected with a mixture of virus $Y$ strains, the results of the indicator plant testing did not confirm the RT-PCR data.

\section{Discussion}

Conservation, study and reproduction of wild relatives of the tuber-bearing Solanum spp. is carried out in the field gene bank of VIR located on the territory of the Science and Production Base "Pushkin and Pavlovsk Laboratories of VIR" in Pushkin town. For over 40 years, the reproduction and study of the collection of varieties, breeding clones and species belonging to section Petota of the genus Solanum L., as well as the production of TPS of tuber-bearing Solanum species has been carried out here. A characteristic feature of the agrocenosis that had formed here is the local concentration of genetic diversity of cultivated forms and wild relatives of potatoes, which is favorable for the manifestation of diseases and the development of pests. Probably, the populations of 
Table 4. PVY detection in Solanum and N. tabacum plants by a complex of methods

\begin{tabular}{|c|c|c|c|c|c|}
\hline \multirow[t]{2}{*}{ Species } & \multirow{2}{*}{$\begin{array}{l}\text { VIR Catalog } \\
\text { number } \\
\text { (genotype) }\end{array}$} & \multicolumn{3}{|c|}{ Detection of PVY in Solanum spp. } & \multirow{2}{*}{$\begin{array}{l}\text { RT-PCR } \\
\text { of } N . \text { tabacum }\end{array}$} \\
\hline & & ELISA & RT-PCR & N. tabacum (symptoms) & \\
\hline S. alandiae & 21240 & PVY & $\mathrm{PVY}$ & Mosaic & - \\
\hline S. avilesii & 20158 & PVY & PVYO & $»$ & PVYO \\
\hline S. avilesii & 20884 & PVY & PVYO & $»$ & PVYO \\
\hline S. cardiophyllum & 24375 & n.d. & $\begin{array}{l}\text { PVYO }{ }^{\circ} \text { PVYNTN-NW } \\
\text { (SYRI) и SYRIIII }\end{array}$ & No & $P V Y^{O}, P V Y^{N T N-N W}$ \\
\hline S. chacoense & 21321 & PVY & $P V Y^{O}$ & Veinal necrosis & $\mathrm{PVY}$ \\
\hline S. chacoense & 22687 & PVY & PVYO & 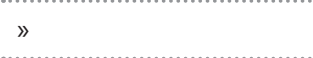 & - \\
\hline S. fendleri & 5751 & n.d. & PVYO & No & - \\
\hline S. hjertingii & 15194 & n.d. & $P V Y^{O}, P V Y^{N} W(A)$ & $"$ & - \\
\hline S. iopetalum & 24393 & PVY & $P V Y^{O}, P V Y^{N} W(A)$ & Mosaic & $P V Y^{N} W(A)$ \\
\hline S. jamesii & $24920(221)$ & PVY & PVYO & Veinal necrosis & $P V Y^{O}, P V Y^{N}$ \\
\hline S. jamesii & $24920(223)$ & PVY? & $P V Y^{O}, P V Y^{N} W(A)$ & Mosaic & n.d. \\
\hline S. kurtzianum & 20038 & PVY & $P V Y^{O}$ & Veinal necrosis & $P V Y^{O}$ \\
\hline S. leptophyes & 5764 & n.d. & n.d. & No & - \\
\hline S. neocardenasii & 24612 & n.d. & n.d. & $»$ & - \\
\hline S. pinnatisectum & $21955(387)$ & n.d. & $\mathrm{PVY}^{\mathrm{O}}$ ? & $»$ & - \\
\hline S. pinnatisectum & 21955 (401) & n.d. & $P V Y^{O}, P V Y^{N} W(A)$ & $»$ & - \\
\hline S. polytrichon & 18142 & PVY & PVYO & Mosaic & PVYO \\
\hline S. polytrichon & 24410 & n.d. & $P V Y^{O}, P V Y^{N} W(A)$ & $»$ & $P V Y^{O}, P V Y^{N} W(A)$ \\
\hline S. polytrichon & 24462 & PVY & PVYO & $»$ & PVYO \\
\hline S. simplicifolium & 12658 & PVY & PVYO & No & n.d. \\
\hline S. spegazzinii & 11431 & PVY & $P V Y^{O}$ & Veinal necrosis & - \\
\hline
\end{tabular}

Note: PVY? - weak reaction; n.d. - PVY not detected; “-” no PCR performed.

phytopathogens attacking potato collection plantings are highly polymorphic, which ensures survival of the parasites in interaction with the population of the host plant. This assumption is confirmed by the results of a comparative analysis of Phytophthora infestans isolates (late blight pathogen) collected from the leaves of potato accessions in the VIR field genebank and of the commercial plantings of potato varieties in the Leningrad Province (Kuznetsova et al., 2016; Sokolova et al., 2017).

The authors have discovered a diversity of virus $\mathrm{Y}$ isolates, including those of the recombinant type, in plants of different Solanum species. For the first time, PVY- ${ }^{\mathrm{N} W}(\mathrm{~A}), \mathrm{PVY}^{\mathrm{NTN}-\mathrm{NW}}$ (SYRI) and SYR III isolates were found in plants of potato relatives in the North-West District of Russia. Earlier, isolates of recombinant PVY ${ }^{\mathrm{NTN}}$ and $\mathrm{PVY}{ }^{\mathrm{N}: \mathrm{O}}$ strains were found in seed potatoes from the central regions of Russia and Belarus (Uskov et al., 2016).

When testing some plants of Solanum spp. (genotypes of $S$. cardiophyllum, S. chacoense, S. hjertingii, S. fendleri, S. kurtzianum, S. pinnatisectum, S. simplicifolium and S. spegazzinii) for PVY presence by a complex of methods (immunological, molecular and biological), contradictory results have been obtained.

The multiplex PCR for the identification of 10 PVY strains, including rare recombinant ones, has been developed with the ability to detect mixed infections (Chikh Ali et al., 2010). However, the authors noted the impossibility in some cases of mixed infection to identify the genotype of each strain. In our research, we also came across examples of insufficient match between the obtained amplification products with the diagnostic fragments mentioned in the paper by Chikh Ali et al. (2010) to make accurate identification of all genotypes of PVY strains. Obviously, the quantitative ratio of different genotypes of virus strains in the infected plant can play an important role in multiplex PCR for mixed infections, which can lead to a 'deficiency' or, on the contrary, an "excess" of some diagnostic amplification products for accurate identification of strains. In the biological sense, it can be assumed that strains with different genotypes differ in competitiveness in different species of host plants. This circumstance may explain the discrepancy in the identification of virus strains in potatoes and tobacco after inoculation of the latter. 
The controversial results of virus $\mathrm{Y}$ strains detection in plants of Solanum spp. and N. tabacum L. may be due to genetic differences between wild relatives and potato varieties (Solanum tuberosum L.), which are used for developing and testing diagnostic methods. At present, a classification of PVY strains infecting potatoes will primarily consider the response of varieties with hypersensitivity genes to certain virus strains and the molecular characterization of the virus isolate, while the appearance of necrosis on $N$. tabacum plants will be considered as a secondary symptom (Karasev, Gray, 2013). Probably, changes in the biological or immunological properties of individual virus $Y$ isolates occur at the interaction with a host plant with a different genetic basis, that is, with wild relatives of potatoes, representing other Solanum species. The disturbed structure of the virus shell protein in recombinant strains, for example, prevents ELIZA assay.

The diversity of PVY strains, especially of recombinant ones, is extensively studied using immunological and molecular genetic methods, whereas biological properties have been studied only for a limited number of isolates (Karasev, Gray, 2013; Green et al., 2017). PVY is considered as an interesting model for studying the evolution of a virus, which is influenced by selection when interacting with genetically different host plants and in different environmental conditions. By evolving through mutations and recombinations between different strains, PVY is able to overcome the resistance of potato varieties with $N$-genes. It has been established that PVYN$\mathrm{W}$ or $\mathrm{PVY}^{\mathrm{N}: \mathrm{O}}$ strains that have spread in potatoes recently, have resulted from the recombination of isolates belonging to common PVYO and necrotic PVYN strains. More than 30 recombinant strain variants have been discovered, the appearance of which is explained by recombination between isolates of different subgroups of strains, including the recombinant isolates that had appeared previously (Green et al., 2018). The PVY isolates with atypical characters found in plants of $S$. cardiophyllum, S. chacoense and S. kurtzianum, are of particular interest for further research.

\section{Conclusions}

PSTVd was not detected in plants of tuber-bearing Solanum species in the VIR field genebank, however potato mosaic viruses were found to be widespread. A great part of clones of wild relatives of potato (Solanum species) selected for late blight and golden nematode resistance, are susceptible to viruses $\mathrm{Y}, \mathrm{S}, \mathrm{M}, \mathrm{X}$.

In the studied set of plants of tuber-bearing Solanum species infected with virus $\mathrm{Y}$, the usual $\mathrm{PVY}^{\mathrm{O}}$ strain prevails, while the second most commonly distributed is the recombinant $\mathrm{PVY}^{\mathrm{N}} \mathrm{W}$ (A) strain. Virus $\mathrm{Y}$ isolates with different biological and immunological properties were found in plants of Solanum spp.

\section{References}

Bukasov S.M. Principles of potato taxonomy. Trudy po Prikladnoy Botanike, Genetike i Selektsii = Proceedings on Applied Botany, Genetics and Breeding. 1978;62(1):3-35. (in Russian)

Chikh Ali M., Maokac T., Natsuakid K.T., Natsuaki T. The simultaneous differentiation of Potato virus Y strains including the newly described strain PVYNTN-NW by multiplex PCR assay. J. Virol. Methods. 2010;165:15-20. DOI 10.1016/j.jviromet.2009.12.010.

Clark M., Adams A. Characteristics of the microplate methods of enzyme-linked immunosorbent assay for the detection of plant viruses. J. Gen. Virol. 1977;34(3):475-483. https://www.ncbi. nlm.nih.gov/pubmed/323416.

Gorbatenko L. South-American potato species (Petota Dumort. section, Solanum L. genus). Catalog of the VIR Global Collection, No. 569. Leningrad, 1990. (in Russian)

Green K., Brown C., Gray S., Karasev A. Phylogenetic study of recombinant strains of potato virus Y. Virology. 2017;507:4052. DOI 10.1016/j.virol.2017.03.018.

Green K., Brown C., Karasev A. Genetic diversity of potato virus Y (PVY): sequence analyses reveal ten novel PVY recombinant structures. Arch. Virol. 2018;163:23-32. DOI 10.1007/ s00705-017-3568-x.

Jeffries C. FAO/IPGRI Technical Guidelines for the Safe Movement of Germplasm. Potato. Rome: IPGRI, 1998;19.

Karasev A., Gray S. Continuous and emerging challenges of Potato virus $Y$ in potato. Annu. Rev. Phytopathol. 2013;51:571586. DOI 10.1146/annurev-phyto-082712-102332.

Kuznetsova M.A., Kozlovsky B.E., Beketova M.P., Sokolova E.A., Malyuchenko O.P., Alekseev Ya.I., Rogozina E.V., Khavkin E.E. Phytopathological and molecular characteristics of Phytophthora infestans isolates collected on resistant and susceptible potato genotypes. Mikologiya i Fitopatologiya = Mycology and Phytopathology. 2016;50(3):175-184. https:// elibrary.ru/item.asp?id=26040085. (in Russian)

Lorenzen J.H., Piche L.M., Gudmestad N.C., Meacham T., Shiel P. A multiplex PCR assay to characterize Potato virus $Y$ isolates and identify strain mixtures. Plant Dis. 2006;90:935-940. DOI 10.1094/PD-90-0935.

Machida-Hirano R. Diversity of potato genetic resources. Breed. Sci. 2015;65(1):26-40. DOI 10.1270/jsbbs.65.26.

Potato Biology and Biotechnology Advances and Perspectives. Eds. D. Vreugdenhil, J. Bradshaw, C. Gebhardt, F. Govers, M. Taylor, D. MacKerron, H. Ross. Amsterdam: Elsevier, 2007.

Rogozina E.V., Khavkin E.E., Kuznetsova M.A., Gavrilenko T.A., Chalaya N.A., Beketova M.P., Sokolova E.A., Antonova O.Yu., Fadina O.A., Smetanina T.I. Catalog of the VIR World Collection, No. 816. Clonal Collection of Wild Potato Species. St. Petersburg, 2015. (in Russian)

Sokolova E.A., Kuznetsova M.A., Ulanova T.I., Rogozhin A.N., SmetaninA T.I., Demidova V.N., Beketova M.P., Malyuchenko O.P., Alekseev Ya.I., Rogozina E.V., Khavkin E.E. Pathogenicity of East European strains of Phytophtho$r a$ infestans vs. resistance of colonized potato plants: the profiles of $A V R$ genes vs. $R$ gene pyramids. PPOSpecial Report. 2017;18:259-268. https://library.wur.nl/ WebQuery/wurpubs/fulltext/448972\#page=261.

Sun Q., Zhang C.Q., Meng Z.D., Zhang F.J., Mu C.H., Li W.C., Zhang Q.W. Establishment on the methods of detecting potato virus X and Y by complex RT-PCR. J. Agr. Biotech. 2009;17: 737-738.

Uskov A.I., Varitsev Yu.A., Biryukova V.A., Galushka P.A., Varitseva G.P., Shmyglya I.V., Kravchenko D.V. Study of the strain composition of potato $\mathrm{Y}$ virus from different regions of the Russian Federation and Belarus. Zemledelie = Agriculture. 2016;8:36-38. (in Russian) 
Vincent H., Wiersema J., Kell S., Fielder H., Dobbie S., Castañeda-Álvarez N.P., Guarino L., Eastwood R., Leo B., Maxted N. A prioritized crop wild relative inventory to help underpin global food security. Biol. Conserv. 2013;167:265-275. DOI 10.1016/j.biocon. 2013.08.011.
Yanagisawa H., Shiki Y., Matsushita Y., Ooishi M., Takaue N., Tsuda S. Development of a comprehensive detection and identification molecular based system for eight pospiviroids. Eur. J. Plant Pathol. 2017;149(1):11-23. DOI 10.1007/s10658-0171157-1.

\section{ORCID ID}

E.V. Rogozina 0000-0002-2743-068X

Acknowledgements. The work was performed in accordance with the State Assignment by the Ministry of Education and Science of the Russian Federation Project No. 0662-2019-0004 (The N.I. Vavilov All-Russian Institute of Plant Genetic Resources, VIR). Molecular identification of PVY virus strains and PSTVd viroid was conducted in All-Russian Institute of Plant Protection (VIZR) due to support the Comprehensive Program of Scientific Research "Development of potato breeding and seed production".

We thank I.V. Shmyglya, Leading Researcher of the Bioengineering Laboratory at the A.G. Lorkh Potato Research Institute, for the provided in vitro plants of 'Osen' variety infected with PSTVd and used as the positive control.

Conflict of interest. The authors declare no conflict of interest.

Received November 13, 2018. Revised January 3, 2019. Accepted January 14, 2019. 